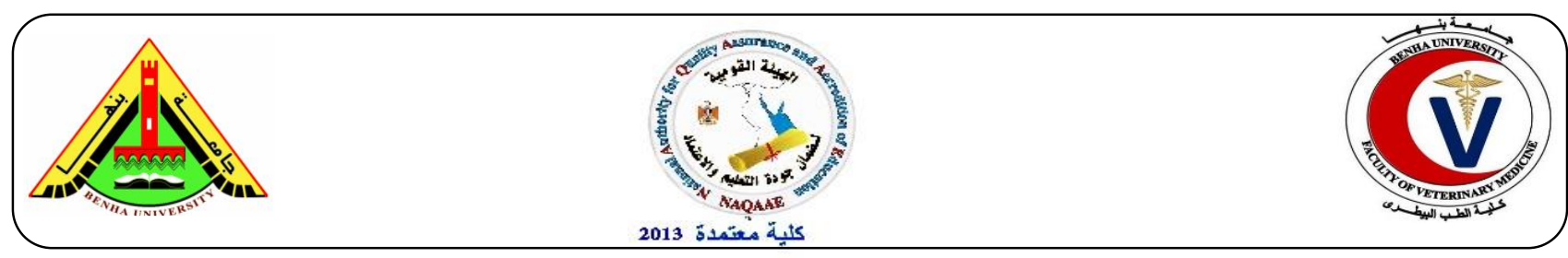

\title{
Prevalence of some pathogenic organisms in cattle carcasses
}

\author{
Saad M. Saad ${ }^{1}$, Mohi E. Ali ${ }^{2}$, Manal O. A. Awadeen ${ }^{3}$ \\ ${ }^{1}$ Department of Food Hygiene and Control, Faculty of Veterinary Medicine, Benha University \\ ${ }^{2}$ Animal Health Research Institute, El Arish, North Sini branch \\ ${ }^{3}$ Animal Health Research Institute, Shibin El Koom branch
}

\begin{abstract}
A B S T R A C T
One hundred random samples of cattle meat, liver, kidney and heart ( 25 of each) were collected from Shibin El-Kom abattoir, Menoufia, Egypt. All the collected samples were examined for demonstration of E. coli, Salmonellae and S. aureus. The result indicated that incidence of E coli, Salmonella and S. aureus were 36\%, $28 \%$ \& $56 \%$ for meat samples; $40 \%, 36 \%$ and $60 \%$ for heart samples; $52 \%, 44 \%$ and $72 \%$ for liver samples and $68 \%, 48 \%$ and $80 \%$ for kidney samples respectively. Further, E. coli, Salmonellae and S. aureus were serologically identified. The incidences of $S$. aureus enterotoxins in the examined samples of cattle were recorded. Enterotoxin A was detected in meat, liver and kidney samples and enterotoxin B from the kidney sample, enterotoxin D from the meat samples, A \& C from heart and kidney and C \& D from liver samples. Accurately, E coli strains were the resistant antibiotics against Erythromycin and Streptomycin. While, Salmonellae was resistant to Oxacillin and Streptomycin, however, S. aureus strains were resistant to Neomycine and Kanamycine.
\end{abstract}

Keywords: E. coli, Salmonellae, S. aureus enterotoxins and antibiotics

(http://www.bvmj.bu.edu.eg)

(BVMJ-36(2): 1252-255, 2019)

\section{INTRODUCTION}

Meat is the most palatable of food article of healthy animals, which may be contaminated during different slaughtering steps as well as during transporting to meat retailers (Ercolini et al. 2006). Meat has high nutritive value for human consumption because it is important source for protein, fat, essential amino acids, minerals, vitamins and other nutrients. On the other hand, meat is considered as an ideal culture media for growth of many organisms because of the high moisture content, the high percentage of nitrogenous compounds, good supply of minerals, glycogen and of a favorable $\mathrm{pH}$ for most microorganisms (Al-Mutairi, 2011). Meat may be contaminated with numerous types of pathogenic microorganisms as E. coli, Salmonellae and $S$. aureus which render meat hazardous to human health (Nørrung et al. 2009). Moreover, E. coli causes several human foodborne diseases these diseases resulting in gastrointestinal symptoms (diarrhea to bloody diarrhea and dysentery), urinary tract complication (hemolytic uremic syndrome (HUS)), pneumonia and meningitis (Johnson et al. 2006). Salmonella has been considered as a significant food-borne disease and could be isolated from raw meat, poultry and their products. Incomplete cooking, inappropriate food processing and reheating food are predisposing factors for occurrence of Salmonella disease (Gorman et al. 2002). Staphylococcal foodborne intoxication occurs all over the world and caused by ingestion of already formed $S$. aureus enterotoxins in food causing clinical signs as vomition, diarrhea and even death in older people and children (Baumgartner et al. 2014). The circumstances at which the animal raised up, slaughtered and carcass preparation are mostly affect the microbial load of the carcass in the abattoir. At first, carcass contamination takes place at the point of first skin cut and the following contamination occurs due to dust produced by removal of hide, workers hands or by contact between dirty hide and subcutaneous connective tissue (Zweifel et al. 2008). The degree of bacterial contamination of animal carcass differs according to plant sanitation. It is also affected by numerous factors as plant lay out, rapidity of slaughtering operation, good 
manufacture practices performed and skillfulness of the slaughtering plant workers (Alegre and Buncic, 2004). The current study was applied to investigate E. coli, Salmonellae and S. aureus as well as Enterotoxins produced by some isolated S.aureus strains in cattle carcasses at Menofia governorate.

\section{Materials and methods}

\subsection{Collection of samples:}

A total of 100 random samples of cattle carcasses represented by meat (neck region), heart, liver and kidney ( 25 of each) were collected from Shibin El-Kom abattoir, Menoufia, Egypt. Each sample was kept in a separate sterile plastic bag and preserved in an ice box then transferred to the laboratory under complete aseptic conditions without undue delay. The collected samples were subjected to bacteriological examination.

\subsection{Preparation of sample (APHA, 2001):}

Twenty five grams of each sample were transferred to a sterile blender jar and $225 \mathrm{ml}$ of $0.1 \%$ sterile buffered peptone water were aseptically added to the content of the jar. Each sample was then homogenized in the blender at $2000 \mathrm{rpm}$ for 1-2 minutes to provide a homogenate, from which tenth-fold serial dilutions were prepared.

\subsection{Examination of samples for bacterial contamination and S. aureus entertoxins :}

Determination of total Staphylococci count was carried out according to ICMSF (1996). Isolation and identification of $\mathrm{E}$. coli was done according to APHA (1984). Isolation and identification of E. coli was done according to APHA (1984). Serological Identification was applied according to Kok et al. (1996). Isolation and identification of Salmonellae was done according to ISO 6579 (2002). Serological identification of Salmonellae was applied according to Kauffman white scheme (Kauffman. 1974).

\subsection{Antimicrobial Sensitivity test:}

It was performed to E. coli, Salmonellae and S. aureus, according to Koneman et al. (1997).

\section{RESULTS}

Table(1) indicated that the incidence of $S$. aureus in cattle samples was $56 \%, 60 \%, 72 \%$ and $80 \%$, while incidence of Salmonella was $28 \%$, $36 \%, 44 \%$ and $48 \%$ but incidence of $E$. coli was $36 \%, 40 \%, 52 \%$ and $68 \%$ from meat, heart, liver and kidney, respectively. Table(2) declared that enterotoxins in examined samples of meat, heart, liver and kidney samples were $0 \%, 4 \%, 4 \%$ and $8 \%$ for enterotoxins $\mathrm{A}$, respectively and $0 \%, 0 \%$, $0 \%$ and $4 \%$ for enterotoxins B. Also, $4 \%, 0 \%$, $0 \%$ and $0 \%$ for enterotoxins C. $0 \%, 4 \%, 0 \%$ \& $4 \%$ for enterotoxins $\mathrm{A} \& \mathrm{C}$ and $0 \%, 0 \%, 4 \% \&$ $0 \%$ for enterotoxins $\mathrm{C} \& \mathrm{D}$, respectively.

Results recorded in table (3) indicated that $S$. aureus count $(\mathrm{cfu} / \mathrm{g})$ in examined samples of meat, heart, liver and kidney was $4.03 \times 10^{2} \pm$ $0.75 \times 10^{2}, \quad 9.61 \times 10^{2} \pm 2.12 \times 10^{3}, \quad 1.44 \times 10^{3} \pm$ $0.60 \times 10^{3}$ and $3.83 \times 10^{3} \pm 0.47 \times 10^{3}$

Table (1) Incidence of $S$. aureus, Salmonellae and $E$. coli in the examined samples of bovine carcasses at Shibin El Kom abattoir

\begin{tabular}{lccc}
\hline $\begin{array}{l}\text { Bovine } \\
\text { samples }\end{array}$ & S.aureus & Salmonella & E. coli \\
\hline Meat & $56 \%$ & $28 \%$ & $36 \%$ \\
Heart & $60 \%$ & $36 \%$ & $40 \%$ \\
Liver & $72 \%$ & $44 \%$ & $52 \%$ \\
Kidney & $80 \%$ & $48 \%$ & $68 \%$ \\
\hline
\end{tabular}

Table (2) incidence of enterotoxins of $S$. aureus detected in the examined samples of bovine carcasses at Shibin El Kom abattoir

\begin{tabular}{lcccc}
\hline Enterotoxins & $\begin{array}{r}\text { Meat } \\
(25)\end{array}$ & $\begin{array}{c}\text { Heart } \\
(25)\end{array}$ & $\begin{array}{r}\text { Liver } \\
(25)\end{array}$ & $\begin{array}{c}\text { Kidney } \\
(25)\end{array}$ \\
\hline A & 0 & 4 & 4 & 8 \\
B & 0 & 0 & 0 & 4 \\
D & 4 & 0 & 0 & 0 \\
A \& C & 0 & 4 & 0 & 4 \\
C \& D & 0 & 0 & 4 & 0 \\
\hline
\end{tabular}

Table (3) Statistical analysis of $S$. aureus counts/g in the examined samples of bovine carcass at Shibin El Kom abattoir $(\mathrm{n}=25)$

\begin{tabular}{lccc}
\hline $\begin{array}{l}\text { Bovine } \\
\text { samples }\end{array}$ & Min & Max & Mean \pm S.E $^{*}$ \\
\hline Meat & $10^{2} \times 1.0$ & $10^{2} \times 7.0$ & $10^{2} \pm \times 4.03$ \\
& & & $10^{2} \times 0.75$ \\
Heart & $10^{2} \times 1.0$ & $10^{3} \times 3.0$ & $10^{2} \pm \times 9.61$ \\
& & & $10^{3} \times 2.12$ \\
Liver & $10^{2} \times 1.0$ & $10^{3} \times 4.0$ & $10^{3} \pm \times 1.44$ \\
& & & $10^{3} \times 0.60$ \\
Kidney & $10^{2} \times 1.0$ & $10^{3} \times 9.0$ & $10^{3} \pm \times 3.83$ \\
& & & $10^{3} \times 0.47$ \\
\hline
\end{tabular}

\section{DISCUSSION}

Incidence of $S$. aureus was the highest Incidence of the all isolates in examined samples while Salmonella was higher than $E$. coli. These results were due to mishandling of the carcasses in slaughterhouse and bad hygienic condition. These findings were agreed with those recorded by 
Elshafay (2014) and Adwan et al. (2015). While, such results disagreed with those reported by Adugna (2014).The presence of staphylococci including $S$. aureus is considered as a good indicator for personal hygiene of factory workers with respiratory infection and suppurative lesions. Therefore, Staphylococci continue to be an important problem for food processors, food service works and consumers. Incidence of S. aureus, Salmonellae and E. coli in kidney and liver samples is higher than that in meat and heart samples.Incidence of $\mathrm{SE}_{S} \mathrm{~A}$ was more than other types of SEs. Nearly similar results were obtained by Ibrahim Rahmi et al. (2013) and Mohammed et al. (2014). Statistical analysis of $S$. aureus count indicated that kidney and liver samples were highly contaminated as compares with meat and heart samples. Concerning antibiotic susceptibility of the isolated pathogens, $E$ coli strains were the resistant antibiotics against Erythromycin and Streptomycin. While, Salmonellae was resistant to Oxacillin and Streptomycin, however, S. aureus strains were resistant to Neomycine and Kanamycine.

\section{REFERENCES}

"ICMSF" International commission of Microbiological Specification for Foods 1996. Microorganisms in Foods. I. Their Significance and methods of enumeration. $3 \mathrm{rd}$ Ed. Univ. of Toronto, Canada.

Adugna, F. 2014. Studies on the prevalence, antibiogram, assessment of risk factors and public health significance of S. aureus in beef and environment at Addis Ababa.M.Sc.Thesis. Depart. Of Vet. Microbiol. Immunol. And Pub. Health M.Sc. Program in Vet.Pub.Health .Bishoftu, Ethiopia.

Adwan, G. M., Alqarem, B. R. and Adwan, K. M. 2015. Prevalence of foodborne pathogens in meat samples in Palestine. Inter. Food Res. J. 22(5): 1806-1812.

AI-Metairie, M.F. 2011. The Incidence of Enterobacteriaceae Causing food Poisoning in some meat products. J. of food Sci. and Technol., 3 (2): 116-121.

Alegre, L. and Buncic, S. 2004. Potential for use of hide-carcass microbial counts relationship as an indicator of process hygiene performance of cattle abattoirs. Food Prot. Tren., 24: 814-820.

APHA (American Public Health Association) 2001. Compendium of methods for microbiological examination of foods. $4^{\text {th }}$ Edition 365-366- 800. $1^{\text {st }}$, NW Washington DC2000 1-3710.

APHA (American Public Health Association) 1984. Compendium of Methods for microbiological examination of foods. American public Health Association, Washington, D.C., USA, 97 (2): 97 - 105.

Baumgartner, A.; Niederhauser, I. and Johler, S. 2014. "Virulence and Resistance Gene Profiles of Staphylococcus aureus Strains Isolated from Ready-to-Eat Foods". J- Food Protect., 7:1232-1236.

Cruickshank.; Duguid, J. P.; Marmion, B. D. and Swaing, R. H. A. 1975. Medical Microbiology. The practice of medical microbiology VII. 12 $2^{\text {th }}$ Ed., Churchill, Livingstones, Edinburgh.

Elshafay, M. 2014. Food safety of cattle meat and offal at abattoir level.M.V.Sc. Thesis (Meat Hygiene) Fac. Vet. Med. Benha Uni.

Ercolini D.; Russo, F.; Torrieri, E.; Masi, P. and Villani, F. 2006. Changes in the spoilagerelated microbiota of beef during refrigerated storage under different packaging conditions. Appl. Environ. Microbiol. 72 (7): 4663-4671.

Gorman, R.; Bloomfield, S. and Adley Catherine C. 2002. A study of crosscontamination of food-borne pathogens in the domestic kitchen in the Republic of Ireland. Int. J. Food Microbiol. , 76(12):143-150.

Ibrahim - Hemmat, I.; Amin - Reham, A.; Saleh - Omima, A. and El Shafay, M.S. 2013. Quality of beef and edible offal at abattoir level. Benha Vet. Med. J., 25(2) : 254 263.

ISO 6579 2002. "Microbiology of food and animal feeding stuffs- horizontal method for the detection of Salmonella spp". International standard. ( $4^{\text {th }}$ edition).

Johnson, J.; Kuskowki, M.; Menard, M.; Gajewski, A.; Xercavins, M. and Garau, J. 2006. Similarity between human and 
chicken E. coli isolates in related to ciprofloxins resistance status. Infect. Dis., 194(1): 71- 78.

Kauffman, G. 1974. Kauffmann white scheme. J. Acta. Path. Microbiol. Sci., 61:385.

Kok, T.; Worswich, D. and Gowans, E. 1996. Some serological techniques for microbial and viral infections. In Practical Medical Microbiology (Collee, J.; Fraser, A.; Marmion, B. and Simmons, A., eds.), $14^{\text {th }}$ ed., Edinburgh, Churchill Livingstone, UK.

Koneman, E.; Allen, S.; Janda, W.; Schreckenberger, C and inn, W. 1997. Color atlas and text book of Diagnostic Microbiology. Fifth Edition. Lippincott, Philadelphia, NewYork.55-73.
Nørrung, B.; Andersen, J. K.and Buncic, S. 2009. Main Concerns of Pathogenic Microorganisms in Meat Safety of Meat and Processed Meat. F. Toldrá, ed. (Springer New York), 3-29.

Quinn, P. J., Markey, B. K., Carter, M. E., Donnelly, W. J. C., Leonard, F. C. and Maguire, D. 2002. "Veterinary microbiology and microbial disease". Iowa State Univ. Press, Blackwell Science Ltd, chapters 26-36: 84-96.

Zweifel, C.;Fischer,R. and Stephen, R. 2008. Microbiological contamination of pig and cattle carcasses in different small-scale Swiss abattoir. J.MeatSci .,78:225-231. 